\title{
The role of estrogen and progesterone receptors in the rotator cuff disease: a retrospective cohort study
}

\author{
Umile Giuseppe Longo ${ }^{1 *}$, Alessandro Mazzola' ${ }^{1}$ Simone Carotti ${ }^{2}$, Maria Francesconi ${ }^{2}$, Simone Catapano ${ }^{1}$, \\ Francesco Magrì ${ }^{1}$, Giuseppe Perrone ${ }^{3}$, Sergio Morini ${ }^{2}$, Sergio De Salvatore ${ }^{1}$ and Vincenzo Denaro
}

\begin{abstract}
Background: Rotator cuff (RC) tears represent a common cause of shoulder pain and dysfunction in adults. The disease affects primarily women and occurs mainly in the postmenopausal period.

This study aimed to investigate immunohistochemically the presence of estrogen receptor-alpha (ER-a), estrogen receptor-beta (ER- $\beta$ ) and progesterone receptor (PR) in the supraspinatus tendon of patients with RC tendinopathy, searching for gender differences of expression. A secondary aim was to evaluate potential links between their expression and the typical histopathological findings of the ailment.

Methods: Biopsies of the supraspinatus tendon were collected intraoperatively from 15 postmenopausal women and 9 men undergoing RC surgery. Specimens were stained with Haematoxylin/Eosin, Masson-Goldner Trichrome, Alcian Blu and immunohistochemical stainings for ER-a, ER- $\beta$ and PR were performed. Tendon alterations were evaluated with the Bonar histopathological scale. Statistical tests used in this study were the Spearman correlation coefficient and the Mann-Whitney $U$ test.

Results: In the supraspinatus tendon, cells expressed ER- $\mathbf{a}(p=0.043)$, ER- $\beta(p=0.048)$ and PR $(p=0.004)$ with statistically significant differences related to age and sex of patients. Immunoreactivity was seen in the nuclei of tenocytes and vascular cells. Postmenopausal women's samples showed a markedly higher expression of these receptors compared to their male counterpart. There was a positive correlation between the expression of ER- $\boldsymbol{a}$ and ER- $\beta$ ( $r=0.59$; $p=0.02)$ and between ER- $\beta$ and PR $(r=0.72 ; p=0.002)$ in women's samples. Furthermore, in postmenopausal women the PR expression decreased with age $(r=-0.56 ; p=0.027)$. Only in women, the ER- $\beta$ expression positively correlated with the total Bonar histopathological score $(p=0.019)$ and the ER- $\beta$ vascular expression positively correlated with ground substance alterations ( $p=0.029)$.
\end{abstract}

Conclusions: These results reveal that ERs and PR are present in the supraspinatus tendon of patients with RC tears, suggesting a role of sex hormones in the pathogenesis of the disease.

Keywords: Estrogen, Progesterone, Receptor, Rotator, Cuff, Tendinopathy, Immunohistochemistry

*Correspondence: g.longo@unicampus.it

1 Department of Orthopaedic and Trauma Surgery, Campus Bio-Medico University, Via Alvaro del Portillo 200, Trigoria, 00128 Rome, Italy

Full list of author information is available at the end of the article

\section{Background}

Rotator cuff (RC) disease is frequent and represents a common cause of shoulder pain, although not all patients are symptomatic $[1,2]$. In the USA, each year approximately 4.5 millions of people suffer from shoulder pain and the majority of them are due to RC tears original author(s) and the source, provide a link to the Creative Commons licence, and indicate if changes were made. The images or other third party material in this article are included in the article's Creative Commons licence, unless indicated otherwise in a credit line to the material. If material is not included in the article's Creative Commons licence and your intended use is not permitted by statutory regulation or exceeds the permitted use, you will need to obtain permission directly from the copyright holder. To view a copy of this licence, visit http://creativecommons.org/licenses/by/4.0/. The Creative Commons Public Domain Dedication waiver (http://creativeco mmons.org/publicdomain/zero/1.0/) applies to the data made available in this article, unless otherwise stated in a credit line to the data. 
$[3,4]$. The prevalence of the disease increases with age, affecting up to $67 \%$ of patients over 80 years $[5,6]$.

Although several risk factors have been identified, actually, the pathogenesis and the natural history of $\mathrm{RC}$ tendinopathy remains unclear [5, 7]. It is considered a multifactorial disease [3] with intrinsic (age, gender, genetic predisposition) and extrinsic (micro and macro-traumas) cofactors that contribute to its onset [8-10]. Recently, endocrine alterations as dysthyroidism [11], hypercholesterolemia and diabetes [12, 13] have been considered potential risk factors.

Numerous studies have indicated that the incidence of repetitive motion disorders occur primarily in females [14] and that asymptomatic full-thickness $\mathrm{RC}$ tears are typically diagnosed in the postmenopausal period [15]. Moreover, in women there is a higher rate of failure, in terms of functional healing, after RC surgery than men [16]. Although the reason of these gender differences remains uncertain, possible explanations include structural alterations in tendon tissue due to the exposure to oscillating levels of female sex hormones [17].

Many authors have investigated the role of female sex hormones and their receptors in the pathogenesis of some musculoskeletal disorders [18-20], including the carpal tunnel syndrome [21], the De Quervain's Syndrome [22] and lesions of the anterior cruciate ligament [23-25].

Estrogens and progesterone are steroid hormones involved in the differentiation and development of the reproductive system, but their influence has been demonstrated also in non-reproductive systems [26]. In order to express their biological activities, female sex hormones have to interact with their specific nuclear receptors, estrogen receptor (ER) and progesterone receptor (PR). There are two different isoforms of ER: ER- $\alpha$ and ER- $\beta$ [27]; also PR presents two isoforms: PR-A and PR-B [28].

As regards the musculoskeletal system, estrogens and progesterone are known to influence fibroblast proliferation and the production of type I collagen [29]. In contrast, menopause is associated with an important reduction of type I collagen content in tendon tissue (the most important structural protein in tendons and ligaments) [30,31]. These structural alterations could be due to low levels of sex hormones and high levels of proinflammatory cytokines (IL-6, TNF-a), that are considered physiological modifications of the postmenopausal period.

This study aimed to investigate immunohistochemically the expression of ER- $\alpha, E R-\beta, P R$ in the supraspinatus tendon of patients with RC tendinopathy. A secondary aim was to evaluate their possible significance in the pathogenesis of the disease.

\section{Methods}

The study enrolled 24 patients representing a consecutive series of patients treated at the orthopedic department of our institution from November 2017 to February 2020. All the patients included in the present study presented chronic shoulder pain and functional impairment. All patients received a preoperative shoulder magnetic resonance imaging (MRI) scan in the affected side. All MRIs were performed with a 1.5-T unit. Full-thickness rotator cuff tears were measured on the sagittal (at the tuberosities) and coronal images and classified into the numbers of tendons torn: small lesions $(<1 \mathrm{~cm}$ of tear and $<1$ tendon involved); medium lesions $(1-3 \mathrm{~cm}$ of tear and 1 tendon involved); large $(3-5 \mathrm{~cm}$ of tear and 2 tendons involved); massive $(>5 \mathrm{~cm}$ of tear and $>2$ tendons involved). Partial-thickness rotator cuff tears were graded in a binary fashion as either grade 1 (less than $50 \%$ torn) or grade 2 (more than $50 \%$ torn) and according to the side torn (either articular or bursal) [32]. Primary aims of the present study were: to investigate immunohistochemically the expression of ER- $a, E R-\beta, P R$ in the supraspinatus tendon of patients with $R C$ tendinopathy, searching for gender differences of expression. Secondary aims of the present study were: to investigate potential links between the expression of ER- $\alpha, E R-\beta, P R$ and the typical histopathological tendon alterations of the RC tendinopathy (according to the Bonar scale [33, 34]). All methods were carried out in accordance with relevant guidelines and regulations. The Ethics committee of Campus Bio Medico of Rome approved the present study and all patients gave written consent to participate. Informed consent was obtained from all participants.

\section{Patients}

None of patients included in the present study had a diagnosis of bilateral RC tendinopathy. All the women enrolled in this study were in menopause. Inclusion criteria were: clinical diagnosis of RC disease; absence of shoulder instability; absence of radiographic evidence of fractures in the humeral head and in the glenoid. Exclusion criteria were: other potential endocrine alterations implicated in the pathogenesis of rotator cuff tendinopathy (disthyroidism, hypercholesterolemia, diabetes), previous surgical treatment in the shoulder; shoulder arthritis; arthrosis of the acromioclavicular or the glenohumeral joint (Tables 1 and 2).

\section{Bioptic samples collection}

Biopsies of the supraspinatus tendon were collected intraoperatively by the First Author (Fig. 1). Samples were harvested during surgery at the myotendineous junction of the pathological supraspinatus tendon by means of arthroscopic instruments. 
Table 1 Demographic data of the female population with RC disease

\begin{tabular}{|c|c|c|c|c|c|c|c|c|}
\hline $\begin{array}{l}\text { Patient } \\
\text { number }\end{array}$ & $\begin{array}{l}\text { Age at } \\
\text { surgery }\end{array}$ & $\begin{array}{l}\text { Age at } \\
\text { Menopause }\end{array}$ & $\begin{array}{l}\text { Hormone } \\
\text { replacement } \\
\text { therapy }\end{array}$ & $\begin{array}{l}\text { Hormone } \\
\text { suppression } \\
\text { therapy }\end{array}$ & $\begin{array}{l}\text { Body Mass } \\
\text { Index (BMI) }\end{array}$ & $\begin{array}{l}\text { Type of tendon } \\
\text { injuries (small; } \\
\text { medium; large; } \\
\text { massive) }\end{array}$ & $\begin{array}{l}\text { Time from } \\
\text { injury/shoulder } \\
\text { pain }\end{array}$ & $\begin{array}{l}\text { Treatments } \\
\text { performed before } \\
\text { surgery }\end{array}$ \\
\hline 1 & 73 & 53 & no & yes & 29.3 & Atraumatic - massive & 6 years & Physical therapy \\
\hline 2 & 64 & 54 & yes & yes & 34.9 & Atraumatic - massive & 6 months & none \\
\hline 3 & 58 & 49 & no & no & 37.7 & Atraumatic - massive & 2 years & none \\
\hline 4 & 58 & 53 & no & no & 20.0 & $\begin{array}{l}\text { Atraumatic - } \\
\text { medium }\end{array}$ & 2 years & none \\
\hline 5 & 69 & 51 & no & no & 29.9 & Atraumatic - massive & 6 years & none \\
\hline 6 & 61 & 51 & no & no & 24.2 & Atraumatic - large & 8 months & Physical therapy \\
\hline 7 & 59 & 52 & no & no & 26.9 & Traumatic - medium & 1 year & none \\
\hline 8 & 74 & 55 & no & no & 26.0 & Atraumatic-massive & 2 years & none \\
\hline 9 & 79 & 50 & no & no & 25.4 & $\begin{array}{l}\text { Atraumatic - } \\
\text { medium }\end{array}$ & 5 months & none \\
\hline 10 & 74 & 48 & no & no & 26.0 & Atraumatic - massive & 2 years & none \\
\hline 11 & 62 & 50 & yes & yes & 27.4 & $\begin{array}{l}\text { Atraumatic - } \\
\text { medium }\end{array}$ & 1 year & Physical therapy \\
\hline 12 & 61 & 53 & no & no & 24.2 & Traumatic - large & 3 months & none \\
\hline 13 & 66 & 51 & no & no & 30.1 & $\begin{array}{l}\text { Atraumatic - } \\
\text { medium }\end{array}$ & 2 years & $\begin{array}{l}\text { Corticosteroid } \\
\text { injections }\end{array}$ \\
\hline 14 & 68 & 49 & no & no & 25.0 & Traumatic -large & 2 years & none \\
\hline 15 & 55 & 50 & no & no & 29.0 & $\begin{array}{l}\text { Atraumatic - } \\
\text { medium }\end{array}$ & 6 months & none \\
\hline
\end{tabular}

Female population: Mean age 63.93 \pm 7.05 ; Mean age at surgery 65.41 \pm 6.94 ; Mean age at menopause 51.27 $\pm 1.95 ;$ Mean BMI 27.73 $\pm 4.24 ;$ Mean duration of symptoms $22.67 \pm 20.93$ months. Full-thickness rotator cuff tears were classified into the numbers of tendons torn: small lesions $(<1 \mathrm{~cm}$ of tear and $<1$ tendon involved); medium lesions ( $1-3 \mathrm{~cm}$ of tear and 1 tendon involved); large ( $3-5 \mathrm{~cm}$ of tear and 2 tendons involved); massive ( $>5 \mathrm{~cm}$ of tear and $>2$ tendons involved). Partial-thickness rotator cuff tears were graded in a binary fashion as either grade 1 (less than $50 \%$ torn) or grade 2 (more than $50 \%$ torn) and according to the side torn (either articular or bursal)

Table 2 Demographic data of the male population with RC disease

\begin{tabular}{|c|c|c|c|c|c|c|}
\hline $\begin{array}{l}\text { Patient } \\
\text { number }\end{array}$ & $\begin{array}{l}\text { Age at } \\
\text { surgery }\end{array}$ & $\begin{array}{l}\text { Hormonal } \\
\text { therapy }\end{array}$ & $\begin{array}{l}\text { Body Mass } \\
\text { Index (BMI) }\end{array}$ & Type of tendon injuries & $\begin{array}{l}\text { Time from injury / } \\
\text { shoulder pain }\end{array}$ & Treatments before surgery \\
\hline 1 & 54 & no & 32.2 & Traumatic - massive & 1 year & none \\
\hline 2 & 51 & no & 28.0 & Atraumatic - large & 2 years & Corticosteroid injections \\
\hline 3 & 55 & no & 27.7 & Traumatic - medium & 2 months & none \\
\hline 4 & 77 & no & 26.9 & Atraumatic - massive & 1 year & none \\
\hline 5 & 62 & no & 29.7 & Atraumatic - large & 3 years & none \\
\hline 6 & 59 & no & 26.8 & Traumatic-massive & 1 month & none \\
\hline 7 & 66 & no & 29.0 & Traumatic - massive & 4 months & none \\
\hline 8 & 77 & no & 25.1 & Atraumatic - medium & 2 years & none \\
\hline 9 & 60 & no & 28.7 & Atraumatic - large & 5 months & Physical therapy \\
\hline
\end{tabular}

Male population: Mean age 61.67 \pm 9.02 ; Mean age at surgery $62.33 \pm 8.89$; Mean BMI 28.23 \pm 1.91 ; Mean duration of symptoms $13.33 \pm 11.46$ months

\section{Histopathology and immunohistochemistry}

Laboratory analysis were performed by the Second and Third Authors. After removing, tissue specimens were immediately fixed in buffered formalin $10 \%$ at room temperature (RT) for $24 \mathrm{~h}$. Then they were rinsed in phosphate buffered saline (PBS, pH7.4), dehydrated in an ascending series of alcohol and embedded in paraffin via xylene. Subsequently, 3-5 $\mu \mathrm{m}$ serial sections were cut and processed for Haematoxylin/Eosin, Masson-Goldner Trichrome, Alcian Blu and immunohistochemical stainings.

Immunohistochemical experiments were performed using the indirect technique [35]. Sections were deparaffinised and endogenous peroxidase was blocked by incubation in $3 \%$ hydrogen peroxide for $5 \mathrm{~min}$ at RT. 


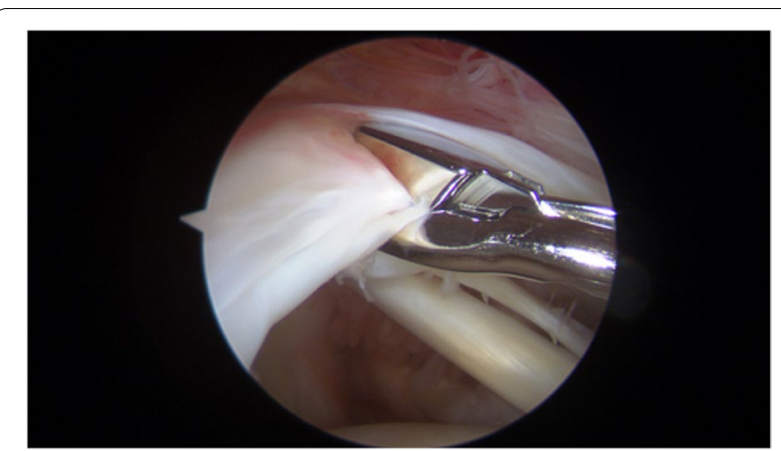

Fig. 1 Withdrawal of the supraspinatus tendon bioptic sample during arthroscopic rotator cuff repair

The following antibodies were used: mouse monoclonal anti-human ER-a (1:100 titre, M7047; Dako - California, USA), rabbit polyclonal anti-human ER- $\beta$ (1:100 titre, SC-8974; Santa Cruz Biotechnology - California, USA), mouse monoclonal anti-human PR (1:100 titre, M3568; Dako - California, USA); the vascularity parameter of the Bonar scale was investigated with a mouse monoclonal antibody anti-CD34 (1:100 titre, clone QBEnd/10 CM084B; Biocare - Italy). After washing with Tris-Buffered saline (TBS), sections were incubated with their primary antibody: ER-a, ER- $\beta$ and PR for $2 \mathrm{~h}$ at $37^{\circ} \mathrm{C}+$ o.n., $\mathrm{CD} 34$ for $2 \mathrm{~h}$ at RT. Preparations were then washed three times with TBS, and incubated with their secondary antibody following the kit protocol Dako EnVision Dual Link System-HRP: antimouse (EnVision FLEX LINKER mouse) for $15 \mathrm{~min}$ and anti-rabbit (EnVision FLEX/HRP) for $30 \mathrm{~min}$. Sections were then washed three times with TBS and finally incubated in diaminobenzidine (DAB, Dako) for $5 \mathrm{~min}$, followed by haematoxylin counterstaining.

Semiquantitative evaluation of immunoreactivity was performed at $\times 40$ magnification in 10 microscopic fields randomly chosen by means of a whole slide scanner Hamamatsu Photonics Nanozoomer Digital Pathology Scanner 2.0RS. For each specimen, the expression of ER- $\alpha$, ER- $\beta$, PR was quantified considering four grades of diffuse immunoreactivity: $0=$ no expression; $1=$ weak expression; $2=$ high expression; $3=$ very high expression. Immunoreactivity for sex steroid receptors was considered separately for tenocytes and vascular cells. Similarly, a semiquantitative analysis of tendinopathy was performed at $\times 4, \times 10, \times 20$ magnification according to the Bonar histopathological scale [33, 34]. It considers four parameters: tenocytes, ground substance, collagen, vascularity. Each parameter is scored with a four-point scoring system, with 0 indicating healthy tissue and III highly degenerated tissue. The final score is comprised between 0 (normal tendon) and 12 (most severe abnormality detectable). Negative control slides processed without primary antibodies were included for each staining. All measurements were performed simultaneously by two observers without knowledge of the patient's data, using a double-headed microscope. Intraobserver agreement was higher than $90 \%$.

\section{Statistical analysis}

Data are expressed as mean and standard deviation $( \pm \mathrm{SD})$. Since the data showed an abnormal distribution, the statistics were performed using the Spearman correlation coefficient and the Mann-Whitney $U$ test. Only $p$ values $<0.05$ were considered to be statistically significant. A priori power analysis was performed for sample size estimation, based on data from the study of Toesca et al. [21], comparing the ER-a tissue expression between women and men. The effect size (ES) in this study was 2.5 , considered to be extremely large according to Cohen's (1988) criteria. With an alpha of 0.05 (two-tailed) and power of 0.80 , the projected sample size needed with this effect size is approximately 8 for this between group comparison. Thus, our proposed sample size of 24 will be more than adequate for the main objective of this study.

\section{Results}

Twenty-seven patients were initially included but 3 were excluded as they had previous surgery. The study enrolled 24 patients treated at our institution. The mean age of patients was 63.08 years $( \pm 7.92$, range 51-78). Bioptic samples of the supraspinatus tendon were collected from 15 women (mean age $63.93 \pm 7.05$ ) and 9 men (mean age $61.67 \pm 9.02$ ) undergoing surgery for RC tears. 27 patients were initially included but 3 were excluded as they had previous surgery. The total Bonar score of supraspinatus tendon specimens ranged from 2 to 10 (mean value $6.58 \pm 1.96$ ). In the female population, the mean value of the total Bonar score was $7.20 \pm 1.51$. In the male population, the mean value of the total Bonar score was $5.56 \pm 2.17$ (Fig. 2). Tissue specimens stained with Haematoxylin/Eosin showed pathological rounded nuclei and an increased cytoplasm in tendon cells, mainly presenting a grade II alteration of tenocyte morphology in men and women. The Alcian Blu staining highlighted ground substance abnormalities in tendon tissue, with increased intrafascicular and then interfascicular amount of glycosaminoglycans (GAG) disarraying collagen fibers. Grade II of ground substance alteration was mainly expressed in women, whereas men showed mainly a grade I. The Masson-Goldner Trichrome staining showed pathological collagen arrangement in tendinopathy, with loss of architecture and separation of fibre bundles. A grade II alteration of collagen arrangement was mainly 

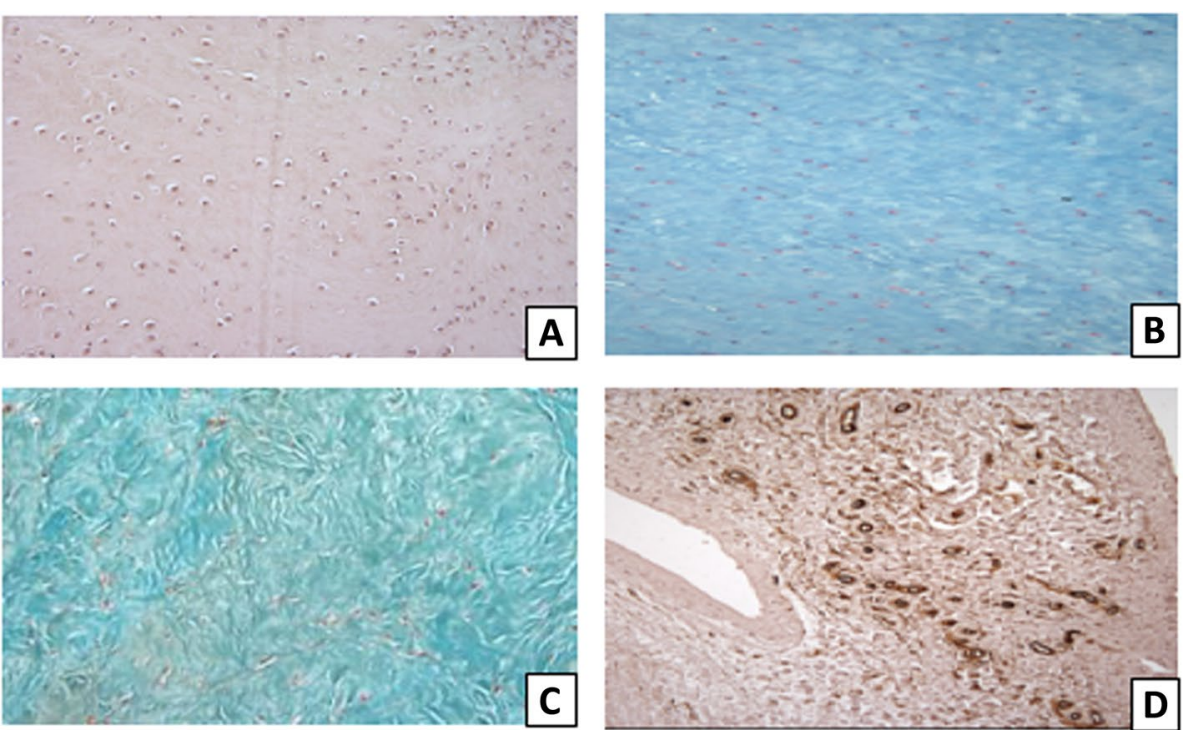

Fig. 2 Histomorphological analysis of the supraspinatus tendon alterations following the Bonar Scale criteria. A Haematoxylin/Eosin showed pathological rounded nuclei and an increased cytoplasm in tendon cells. B Alcian Blu highlighted ground substance abnormalities with increased intrafascicular and interfascicular deposits of GAG. C Masson-Goldner Trichrome showed pathological collagen arrangement, with disorganization of fibre bundles. D CD34 immunohistochemical staining showed pathological neovascularization. Original magnification: $\times 200($ A), $\times 100$ (B, C, D)

observed in men and women. As regards vascularization, tendons showed occasional pathological clusters of capillaries. Grade I and grade III of alteration in vascularity was mainly observed in our female population. Men presented a higher expression of grade I (Tables 3 and 4). The expression of ER-a, ER- $\beta$ and PR in the nuclei of tenocytes and vascular cells was evaluated separately for women and men. Both groups showed the expression of sex steroid receptors in the pathological supraspinatus tendon, with quantitative gender differences of immunoreactivity (Figs. 3 and 4). A four level (from 0 to 3 ) scoring system was adopted in order to quantify tissue immunoreactivity. In the female population, specimens showed high levels of ER-a

Table 3 Semiquantitative evaluation of tendon alterations in women according to the Bonar Scale

\begin{tabular}{lllll}
\hline Variables & Grade 0 & Grade 1 & Grade 2 & Grade 3 \\
\hline Tenocytes & $0(0 \%)$ & $3(20 \%)$ & $8(53.3 \%)$ & $4(26.7 \%)$ \\
Ground substance & $2(13.3 \%)$ & $5(33.3 \%)$ & $7(46.7 \%)$ & $1(6.7 \%)$ \\
Collagen & $0(0 \%)$ & $0(0 \%)$ & $12(80 \%)$ & $3(20 \%)$ \\
Vascularity & $4(26.7 \%)$ & $5(33.3 \%)$ & $1(6.7 \%)$ & $5(33.3 \%)$ \\
\hline
\end{tabular}

Data are absolute values and percentages of positively stained cells in women's samples for the 4 parameters of the Bonar Scale: it allows a semiquantitative analysis of tendinopathy considering alterations of tenocytes, ground substance, collagen and vascularity. Each parameter is scored with a four-point scoring system, with 0 indicating healthy tissue and III highly degenerated tissue. The final score is comprised between 0 (normal tendon) and 12 (most severe abnormality detectable)
Table 4 Semiquantitative evaluation of tendon alterations in men according to the Bonar Scale

\begin{tabular}{lllll}
\hline Variables & Grade 0 & Grade 1 & Grade 2 & Grade 3 \\
\hline Tenocytes & $1(11.1 \%)$ & $2(22.2 \%)$ & $5(55.6 \%)$ & $1(11.1 \%)$ \\
Ground substance & $3(33.3 \%)$ & $4(44.4 \%)$ & $2(22.2 \%)$ & $0(0 \%)$ \\
Collagen & $0(0 \%)$ & $3(33.3 \%)$ & $5(55.6 \%)$ & $1(11.1 \%)$ \\
Vascularity & $2(22.2 \%)$ & $5(55.6 \%)$ & $0(0 \%)$ & $2(22.2 \%)$ \\
\hline
\end{tabular}

Data are absolute values and percentages of positively stained cells in men's samples for the 4 parameters of the Bonar Scale

expression in the nuclei of tenocytes with a grade 3 mainly observed; men presented mainly a grade 1 . The ER-a positivity in the nuclei of vascular cells showed prevalently the expression of grade 0 for both men and women. Similarly, the nuclear expression of ER- $\beta$ in tenocytes of the female group presented mainly a grade 3; men showed an equal expression of grades 1 and 2 . The ER- $\beta$ nuclear expression of vascular cells showed mainly a grade 0 for both men and women. The PR immunoreactivity in the nuclei of tenocytes showed mainly a grade 2 in the female group; men presented mainly a grade 1 . The PR nuclear expression of vascular cells showed mainly a grade 0 for both men and women (Tables 5 and 6). Statistical analysis highlighted a significant gender difference of immunoreactivity for ER- $\beta(p=0.048)$ and $\mathrm{PR}(p=0.004)$, with postmenopausal women showing markedly higher levels of expression than men. No statistically significant 

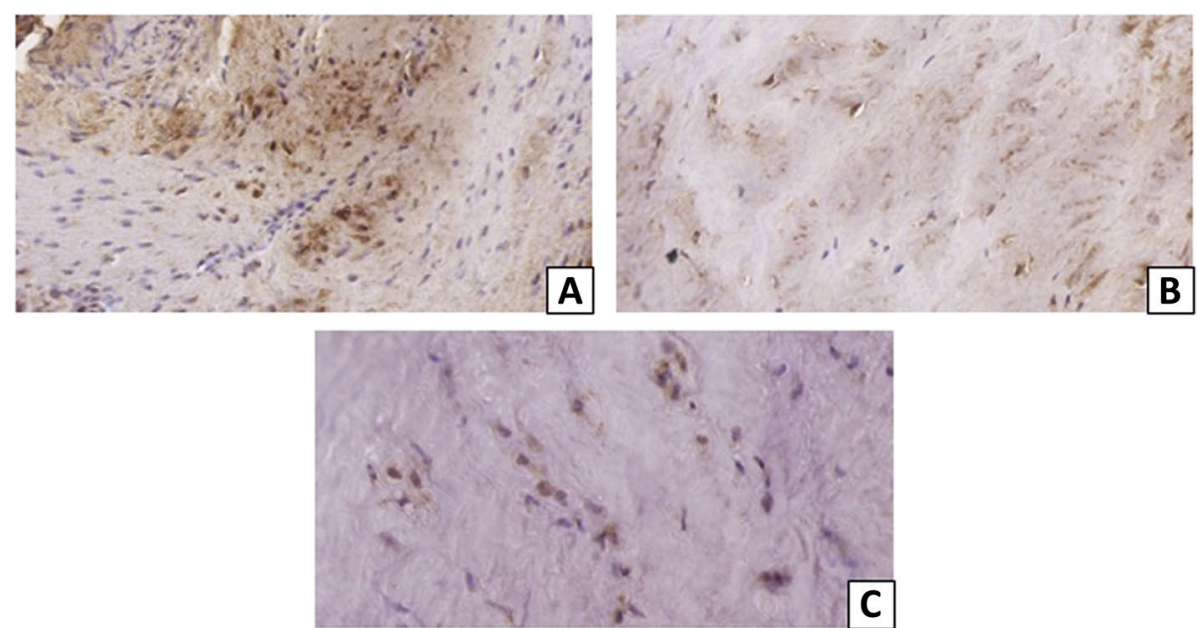

Fig. 3 Immunohistochemical expression of ER- $a, E R-\beta$ and PR in tenocytes of the supraspinatus tendon. A ER-a. B ER- $\beta$. C PR. Original magnification: $\times 40$
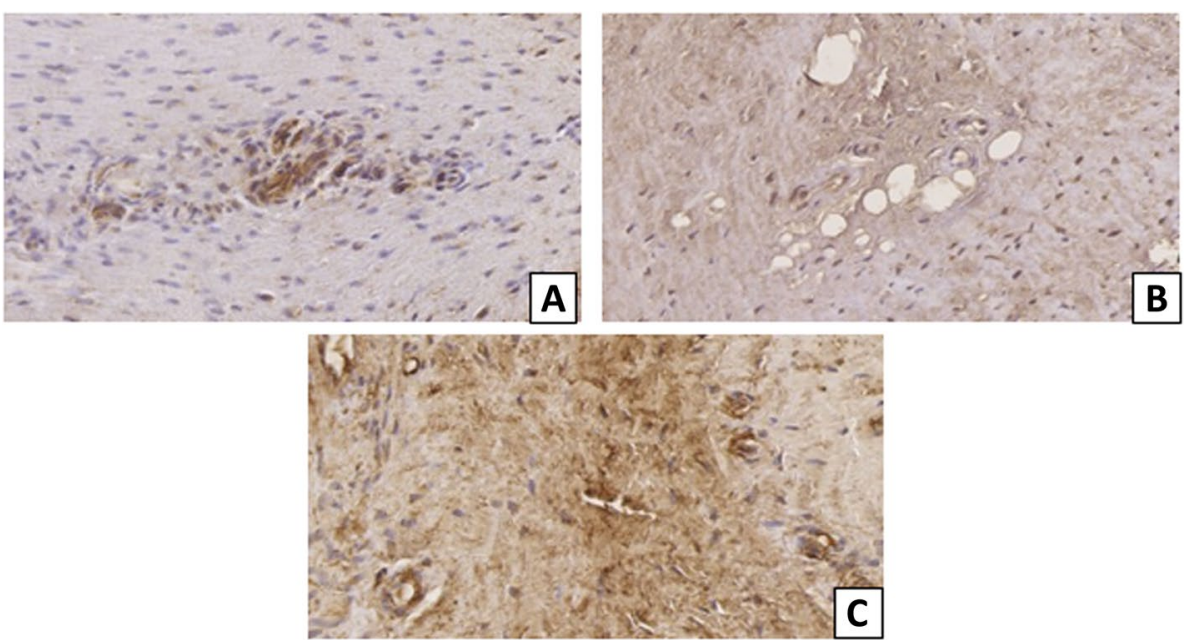

Fig. 4 Immunohistochemical expression of ER- $a, E R-\beta$ and $P R$ in vascular cells of the supraspinatus tendon. A ER-a. B ER- $\beta$. C PR. Original magnification: $\times 40$

Table 5 Semiquantitative evaluation of ER-a, ER- $\beta, \quad P R$ expression in the supraspinatus tendon of women

\begin{tabular}{lllll}
\hline Variables & Grade 0 & Grade 1 & Grade 2 & Grade 3 \\
\hline ER- $\boldsymbol{a}$ tenocytes & $0(0 \%)$ & $3(20 \%)$ & $5(33.3 \%)$ & $7(46.7 \%)$ \\
ER- $\boldsymbol{a}$ vessels & $9(60 \%)$ & $4(26.7 \%)$ & $1(6.7 \%)$ & $1(6.7 \%)$ \\
ER- $\boldsymbol{\beta}$ tenocytes & $0(0 \%)$ & $4(26.7 \%)$ & $5(33.3 \%)$ & $6(40 \%)$ \\
ER- $\boldsymbol{\beta}$ vessels & $8(53.3 \%)$ & $4(26.7 \%)$ & $3(20 \%)$ & $0(0 \%)$ \\
PR tenocytes & $0(0 \%)$ & $3(20 \%)$ & $8(53.3 \%)$ & $4(26.7 \%)$ \\
PR vessels & $8(53.3 \%)$ & $3(20 \%)$ & $3(20 \%)$ & $1(6.7 \%)$ \\
\hline
\end{tabular}

Data are absolute values and percentages of positively stained cells in women's samples for the expression of ER- $a, E R-\beta$, PR in the supraspinatus tendon: it was quantified considering four grades of diffuse immunoreactivity: $0=$ no expression; 1 = weak expression; 2 =high expression; $3=$ very high expression
Table 6 Semiquantitative evaluation of ER-a, ER- $\beta, \quad P R$ expression in the supraspinatus tendon of men

\begin{tabular}{lllll}
\hline Variables & Grade 0 & Grade 1 & Grade 2 & Grade 3 \\
\hline ER- $\boldsymbol{a}$ tenocytes & $0(0 \%)$ & $5(55.6 \%)$ & $3(33.3 \%)$ & $1(11.1 \%)$ \\
ER- $\boldsymbol{a}$ vessels & $8(88.9 \%)$ & $1(11.1 \%)$ & $0(0 \%)$ & $0(0 \%)$ \\
ER- $\boldsymbol{\beta}$ tenocytes & $1(11.1 \%)$ & $4(44.4 \%)$ & $4(44.4 \%)$ & $0(0 \%)$ \\
ER- $\boldsymbol{\beta}$ vessels & $7(77.8 \%)$ & $2(22.2 \%)$ & $0(0 \%)$ & $0(0 \%)$ \\
PR tenocytes & $2(22.2 \%)$ & $5(55.6 \%)$ & $2(22.2 \%)$ & $0(0 \%)$ \\
PR vessels & $8(88.9 \%)$ & $1(11.1 \%)$ & $0(0 \%)$ & $0(0 \%)$ \\
\hline
\end{tabular}

Data are absolute values and percentages of positively stained cells in men's samples for the expression of ER- $\alpha, E R-\beta, P R$ in the supraspinatus tendon 
differences were found between males and females in ER-a tendon expression $(p=0.055)$ (Table 7).

There was a positive correlation between the expression of ER- $\alpha$ and ER- $\beta$ in women's tendon $(r=0.59$; $p=0.02)$. Similarly, there was a positive correlation between ER- $\beta$ and PR in the same group $(r=0.72$; $p=0.002)$. Moreover, a negative correlation in women between age and PR $(r=-0.56 ; p=0.027)$ was found. Only in women, the ER- $\beta$ expression positively correlated with the total Bonar histopathological score $(r=0.64, p=0.01)$ and the ER- $\beta$ vascular expression positively correlated with ground substance alterations $(r=0.62, p=0.014)$. The same analysis performed in men did not show any statistically significant correlation.

\section{Discussion}

Although the exact pathogenesis of $\mathrm{RC}$ tendinopathy is still under debate [5, 7], it is thought to be a multifactorial disease [3], with several cofactors that contribute to weaken tendons until their rupture. Previous studies have indicated that repetitive motion disorders occur mainly in women [14] and in advanced age [5, 6]. It may imply a potential role of postmenopausal hormonal modifications in influencing the natural history of these ailments.

This study showed that both men and women affected by RC tears express nuclear receptors for estrogens and progesterone in tendon cells. Immunoreactivity was found in tenocytes and in vascular cells of the same tissue. The presence of ER- $\alpha, E R-\beta$ and PR in RC tendons indicates that sex steroid hormones may influence the homeostasis of tendon tissue. Consistent with this role, several studies on rats have demonstrated a reduction in collagen content in joint capsules, skin, tendons and arteries after a long-term estrogenic treatment [36-38]. Moreover, in humans estrogens may influence ligament structure modulating the expression of collagen type I and III [23], fibroblast proliferation [25] and inflammatory pathways [39]. These and other hormonal effects may be responsible for structural modifications in tendon tissue, explaining the higher incidence of the disease in women.
It is known that ER- $\alpha$ and ER- $\beta$, the main isoforms of estrogen receptor, can have mutual complex interactions leading to different effects on tissues. On the mammary gland, $17 \beta$-estradiol modulates different signaling pathways depending on the isoform of its receptor: the binding to ER-a promotes cellular proliferation, whereas the binding to ER- $\beta$ inhibits proliferation and favors differentiation [40, 41]. It means that different levels of receptor expression may lead to opposite biological effects on the same tissue. An ER- $\beta$ overexpression has been found in tenocytes and synovial tissue of postmenopausal women with carpal tunnel syndrome, suggesting that ERs may play a role in its pathogenesis [42]. This study showed that ER- $\beta$ and PR are markedly more expressed in postmenopausal women's samples compared to their male counterpart. In contrast, ER-a did not show a statistically significant difference of expression between males and females. Furthermore, only in women there was a positive correlation between the expression of ER- $a$ and ER- $\beta$ and between ER- $\beta$ and PR. These findings suggest that in torn supraspinatus tendons the ER- $\alpha / E R-\beta$ ratio is approximately 1 , but undoubtedly further studies are required to clarify how ERs mutually influence their effects on this tissue.

In postmenopausal women, the ER- $\alpha$ and ER- $\beta$ expression in the supraspinatus tendon did not vary with age. In contrast, the PR expression decreased with age and it is consistent with data from other studies on the transverse carpal ligament [21]. The exact role of PR in the supraspinatus tendon remains unclear, however previous studies on rats have investigated how progesterone may influence the musculoskeletal system: it has been demonstrated that the collagen content of both hip and knee joint capsule is significantly decreased by estrogen or estrogen combined with progesterone [36]. The PR gene (PGR) is a typical ER target gene, therefore the PR expression has been historically used as a biomarker of the ER pathway on a tissue [43]. Many authors have studied how these mutual receptor interactions influence the natural history of breast cancer, wherein the PR expression is considered a positive prognostic factor [44, 45]. Indeed, in breast tissue progestogens (compounds that activate PR) exert an anti-proliferative effect [46] because

Table 7 Gender difference of expression for ER-a, ER- $\beta$, PR in the supraspinatus tendon

\begin{tabular}{|c|c|c|c|c|c|c|}
\hline & \multicolumn{2}{|l|}{ ER-a } & \multicolumn{2}{|l|}{$E R-\beta$} & \multicolumn{2}{|l|}{ PR } \\
\hline & Females & Males & Females & Males & Females & Males \\
\hline Mean $\pm S D$ & $2.3 \pm 0.8$ & $1.6 \pm 0.7$ & $2.1 \pm 0.8$ & $1.3 \pm 0.7$ & $2.1 \pm 0.7$ & $1 \pm 0.7$ \\
\hline $\mathrm{N}$ & 15 & 9 & 15 & 9 & 15 & 9 \\
\hline
\end{tabular}

Statistical analysis highlighted a significant gender difference of immunoreactivity for ER- $\beta$ ( $p=0.048)$ and PR ( $p=0.004)$, with postmenopausal women showing markedly higher levels of expression than men. No statistically significant differences were found between males and females in ER- $a$ tendon expression ( $p=0.055$ ). Data are expressed as mean $\pm S D$ 
PR sequesters ER away from its pro-proliferative gene targets, thereby inhibiting cancer growth [47]. Identification of progesterone effects on the RC tendons may be helpful to understand the interactions with estrogens on this tissue.

In order to investigate potential links between the expression of sex steroid receptor and tendinopathy, we performed a semiquantitative analysis of supraspinatus tendon specimens according to the criteria of the Bonar histopathological scale [33]. The Bonar scale allowed us to stratify patients for the severity of tendinopathy. Results showed a positive correlation in women between the ER- $\beta$ expression and the total Bonar histopathological score. Furthermore, consistently with the rationale of the present research, it was evident only in the female population suggesting that gender differences may influence the pathogenesis of the disease.

Surprisingly, only ER- $\beta$ showed correlations with the histopathological findings of RC tears. It implies that this receptor may play a major role in determining tendon alterations if compared to ER- $\alpha$ and PR. Some authors have reported that the ER- $\beta$ expression is associated with the severity of the De Quervain's Syndrome, hypothesising that estrogens aggravate inflammation and angiogenesis through an increased ER- $\beta$ expression [22]. Moreover, a study on rats has demonstrated that the coexistence of mechanical stress and estrogen deficiency exacerbates tendinopathy through up-regulating the ER- $\beta$-associated apoptosis in tenocytes [48]. In addition, several studies have reported that specific genetic variants of the Estrogen-Related Receptor Beta (ESRRB) gene convey a significantly increased risk of $R C$ tearing and failure of RC healing compared to population controls [49-52]. Additional investigations are needed to clarify how changes in estrogens levels affect biological responses of the shoulder.

Specimens showed immunoreactivity for ER-a, ER- $\beta$ and $P R$ in vascular cells of the supraspinatus tendon, suggesting a potential role of sex hormones in angiogenesis. As a matter of fact, estrogens are known to promote bone angiogenesis [53] and to have vasodilator effects increasing microvascular permeability in the uterus [54-56]. It is possible that sex hormones fluctuations determine modification in blood supply to tendon tissue, altering its homeostasis and predisposing it to injures.

This study also reported a positive correlation between the ER- $\beta$ vascular expression and ground substance abnormalities. The ER- $\beta$ is believed to have roles in promoting cell survival in hypoxic environments $[57,58]$ : in fact it has been shown to interact with the HypoxiaInducible Factor (HIF), stimulating transcription of its target genes [57]. The insertional footprint of the RC is considered a relatively hypoxic microenvironment
[59-61], justifying an elevated ER- $\beta$ expression. Furthermore, studies performed on the RC and on the anterior tibialis tendon revealed that ground substance alterations (such as GAG overexpression and, consequently, fibrocartilagineous chondroid metaplasia) are a functional adaptation to persistent hypoxia in poorly vascularized areas of tendons $[62,63]$. These findings may explain the relationship between ER- $\beta$, vascularization and ground substance alterations reported in the present study, however the role of this process in the pathogenesis of RC tears needs to be demonstrated.

This study has some limitations. Firstly, a relatively small sample size did not allow us to perform large-scale statistical analyses. Secondly, the sparseness of samples from patients less than 50 years old made it difficult to analyse potential modification of the sex steroid receptor expression before and after menopause in tendons. Thirdly, due to the lack of a control group we were unable to compare our findings with normal healthy tissue.

\section{Conclusions}

This is the first study that reveals the expression of estrogen and progesterone receptors in the supraspinatus tendon of patients with RC tendinopathy. Results seem to suggest a potential link between this hormonal expression and the age, the gender and the severity of the typical histopathological alterations of the disease. As reported by several pieces of evidence from other works, the ER- $\beta$ showed the most significant association with tendon abnormalities. It implies that this receptor may play a leading role in altering tendon homeostasis compared to ER-a and PR. The present study tried to shed further light on the unclear pathogenesis of this ailment, suggesting a gender predisposition. However, considering the study design, the lack of a control group, and the lack of data before the tendon rupture, the hormone receptor expression cannot be directly linked to the pathogenesis of the rotator cuff rupture.

The localization of sex steroid hormone receptors in $\mathrm{RC}$ tendons is the first step to understand the potential role of estrogens and progesterone in predisposing shoulder injuries. Additional investigations should be conducted in order to evaluate how sex hormones and their receptors influence biological responses in the RC.

\section{Abbreviations}

RC: Rotator cuff; ER-a: Estrogen receptor-alpha; ER- $\beta$ : Estrogen receptor-beta; PR: Progesterone receptor; MRI: Magnetic resonance imaging; RT: Room temperature; PBS: Phosphate buffered saline; TBS: Tris-buffered saline; DAB: Diaminobenzidine; SD: Standard deviation; GAG: Glycosaminoglycans; PGR: Progesterone receptor gene; ESRRB: Estrogen-Related Receptor Beta; HIF: Hypoxia-Inducible Factor.

\section{Acknowledgements}

Not applicable. 


\section{Authors' contributions}

UGL, AM: manuscript preparation, study design, database interpretation and manuscript revision. UGL, AM, SC: manuscript preparation, database interpretation and statistical analysis. AM, SC, FM, SDS: manuscript preparation, figures and tables preparation, study design. UGL, AM, SC, MF: Manuscript preparation and database interpretation. SM, GP, VD: Study design, manuscript revision. The author(s) read and approved the final manuscript.

\section{Funding}

Not applicable.

\section{Availability of data and materials}

The dataset supporting the conclusions of this article is included within the article.

\section{Declarations}

Ethics approval and consent to participate

The study was conducted according to the guidelines of the Declaration of Helsinki, and approved by the Institutional Review Board of Campus Bio-Medico University of Rome (COSMO study, Protocol number: 78/18 OSS ComEt CBM, 16/10/18).

\section{Consent for publication}

Written informed consent to publish this information was obtained from study participants. All the data are available for the consultation.

\section{Competing interests}

UGL is a member of the Editorial Board of BMC Musculoskeletal Disorders. The remaining authors declare that they have no conflict of interest.

\section{Author details}

${ }^{1}$ Department of Orthopaedic and Trauma Surgery, Campus Bio-Medico University, Via Alvaro del Portillo 200, Trigoria, 00128 Rome, Italy. ${ }^{2}$ Unit of Microscopic and Ultrastructural Anatomy, University Campus Bio-Medico, Rome, Italy. ${ }^{3}$ Department of Human Pathology, University Campus Bio-Medico, Rome, Italy.

Received: 17 April 2021 Accepted: 22 September 2021

Published online: 20 October 2021

\section{References}

1. Tashjian RZ. Epidemiology, natural history, and indications for treatment of rotator cuff tears. Clin Sports Med. 2012;31(4):589-604.

2. Yamamoto A, Takagishi K, Osawa T, Yanagawa T, Nakajima D, Shitara H, et al. Prevalence and risk factors of a rotator cuff tear in the general population. J Shoulder Elb Surg. 2010;19(1):116-20.

3. Longo UG, Berton A, Papapietro N, Maffulli N, Denaro V. Epidemiology, genetics and biological factors of rotator cuff tears. Med Sport Sci. 2012;57:1-9.

4. Longo UG, Salvatore G, Rizzello G, Berton A, Ciuffreda M, Candela V, et al. The burden of rotator cuff surgery in Italy: a nationwide registry study. Arch Orthop Trauma Surg. 2017;137(2):217-24.

5. Codding JL, Keener JD. Natural history of degenerative rotator cuff tears. Curr Rev Musculoskelet Med. 2018;11(1):77-85.

6. Tempelhof S, Rupp S, Seil R. Age-related prevalence of rotator cuff tears in asymptomatic shoulders. J Shoulder Elb Surg. 1999;8(4):296-9.

7. Harvie P, Ostlere SJ, Teh J, McNally EG, Clipsham K, Burston BJ, et al. Genetic influences in the aetiology of tears of the rotator cuff. Sibling risk of a full-thickness tear. J Bone Joint Surg Br. 2004;86(5):696-700.

8. Longo UG, Berton A, Khan WS, Maffulli N, Denaro V. Histopathology of rotator cuff tears. Sports Med Arthrosc Rev. 2011;19(3):227-36.

9. Longo UG, Franceschi F, Ruzzini L, Rabitti C, Morini S, Maffulli N, et al. Histopathology of the supraspinatus tendon in rotator cuff tears. Am J Sports Med. 2008;36(3):533-8.

10. Hsu J, Keener JD. Natural history of rotator cuff disease and implications on management. Oper Tech Orthop. 2015;25(1):2-9.
11. Oliva F, Osti L, Padulo J, Maffulli N. Epidemiology of the rotator cuff tears: a new incidence related to thyroid disease. Muscles Ligaments Tendons J. 2014:4(3):309-14.

12. Carbone S, Gumina S, Arceri V, Campagna V, Fagnani C, Postacchini F. The impact of preoperative smoking habit on rotator cuff tear: cigarette smoking influences rotator cuff tear sizes. J Shoulder Elb Surg. 2012;21(1):56-60.

13. Dunn WR, Kuhn JE, Sanders R, An Q, Baumgarten KM, Bishop JY, et al. Symptoms of pain do not correlate with rotator cuff tear severity: a cross-sectional study of 393 patients with a symptomatic atraumatic fullthickness rotator cuff tear. J Bone Joint Surg Am. 2014;96(10):793-800.

14. Hart DA, Archambault JM, Kydd A, Reno C, Frank CB, Herzog W. Gender and neurogenic variables in tendon biology and repetitive motion disorders. Clin Orthop Relat Res. 1998;(351):44-56.

15. Abate M, Schiavone C, Di Carlo L, Salini V. Prevalence of and risk factors for asymptomatic rotator cuff tears in postmenopausal women. Menopause. 2014;21(3):275-80.

16. Fermont AJ, Wolterbeek N, Wessel RN, Baeyens JP, de Bie RA. Prognostic factors for successful recovery after arthroscopic rotator cuff repair: a systematic literature review. J Orthop Sports Phys Ther. 2014;44(3):153-63.

17. Leblanc DR, Schneider M, Angele P, Vollmer G, Docheva D. The effect of estrogen on tendon and ligament metabolism and function. J Steroid Biochem Mol Biol. 2017;172:106-16.

18. Oliva F, Piccirilli E, Berardi AC, Frizziero A, Tarantino U, Maffulli N. Hormones and tendinopathies: the current evidence. Br Med Bull. 2016;117(1):39-58.

19. Frizziero A, Vittadini F, Gasparre G, Masiero S. Impact of oestrogen deficiency and aging on tendon: concise review. Muscles Ligaments Tendons J. 2014;4(3):324-8.

20. Torricelli P, Veronesi F, Pagani S, Maffulli N, Masiero S, Frizziero A, et al. In vitro tenocyte metabolism in aging and oestrogen deficiency. Age (Dordr). 2013;35(6):2125-36.

21. Toesca A, Pagnotta A, Zumbo A, Sadun R. Estrogen and progesterone receptors in carpal tunnel syndrome. Cell Biol Int. 2008;32(1):75-9.

22. Shen PC, Wang PH, Wu PT, Wu KC, Hsieh JL, Jou IM. The estrogen receptor- $\beta$ expression in De Quervain's disease. Int J Mol Sci. 2015;16(11):26452-62.

23. Lee CY, Smith CL, Zhang X, Hsu HC, Wang DY, Luo ZP. Tensile forces attenuate estrogen-stimulated collagen synthesis in the ACL. Biochem Biophys Res Commun. 2004;317(4):1221-5.

24. Liu SH, al-Shaikh R, Panossian V, Yang RS, Nelson SD, Soleiman N, et al. Primary immunolocalization of estrogen and progesterone target cells in the human anterior cruciate ligament. J Orthop Res. 1996;14(4):526-33.

25. Yu WD, Panossian V, Hatch JD, Liu SH, Finerman GA. Combined effects of estrogen and progesterone on the anterior cruciate ligament. Clin Orthop Relat Res. 2001;383:268-81.

26. Syed F, Khosla S. Mechanisms of sex steroid effects on bone. Biochem Biophys Res Commun. 2005;328(3):688-96.

27. Pavao M, Traish AM. Estrogen receptor antibodies: specificity and utility in detection, localization and analyses of estrogen receptor alpha and beta. Steroids. 2001;66(1):1-16.

28. Horwitz KB, Alexander PS. In situ photolinked nuclear progesterone receptors of human breast cancer cells: subunit molecular weights after transformation and translocation. Endocrinology. 1983;113(6):2195-201.

29. Hansen M, Kongsgaard M, Holm L, Skovgaard D, Magnusson SP, Qvortrup $K$, et al. Effect of estrogen on tendon collagen synthesis, tendon structural characteristics, and biomechanical properties in postmenopausal women. J Appl Physiol (1985). 2009;106(4):1385-93.

30. Moalli PA, Talarico LC, Sung WW, Klingensmith WL, Shand SH, Meyn LA, et al. Impact of menopause on collagen subtypes in the arcus tendineous fasciae pelvis. Am J Obstet Gynecol. 2004;190(3):620-7.

31. Osakabe T, Hayashi M, Hasegawa K, Okuaki T, Ritty TM, Mecham RP, et al. Age- and gender-related changes in ligament components. Ann Clin Biochem. 2001;38(Pt 5):527-32.

32. Spencer EE, Dunn WR, Wright RW, Wolf BR, Spindler KP, McCarty E, et al. Interobserver agreement in the classification of rotator cuff tears using magnetic resonance imaging. Am J Sports Med. 2008;36(1):99-103.

33. Cook J, Feller JA, Bonar SF, Khan KM. Abnormal tenocyte morphology is more prevalent than collagen disruption in asymptomatic athletes' patellar tendons. J Orthop Res. 2004;22(2):334-8. 
34. Maffulli N, Barrass V, Ewen SW. Light microscopic histology of achilles tendon ruptures. A comparison with unruptured tendons. Am J Sports Med. 2000;28(6):857-63.

35. Sternberger LA, Sternberger NH. The unlabeled antibody method: comparison of peroxidase-antiperoxidase with avidin-biotin complex by a new method of quantification. J Histochem Cytochem. 1986;34(5):599-605.

36. Hama H, Yamamuro T, Takeda T. Experimental studies on connective tissue of the capsular ligament. Influences of aging and sex hormones. Acta Orthop Scand. 1976;47(5):473-9.

37. Fischer GM, Swain ML. Effect of sex hormones on blood pressure and vascular connective tissue in castrated and noncastrated male rats. Am J Phys. 1977;232(6):H617-21.

38. Shikata J, Sanada H, Tamamuro T, Takeda T. Experimental studies of the elastic fiber of the capsular ligament: influence of ageing and sex hormones on the hip joint capsule of rats. Connect Tissue Res. 1979;7(1):21-7

39. Kawasaki T, Ushiyama T, Inoue $K$, Hukuda S. Effects of estrogen on interleukin-6 production in rheumatoid fibroblast-like synoviocytes. Clin Exp Rheumatol. 2000;18(6):743-5.

40. Levin ER. Cell localization, physiology, and nongenomic actions of estrogen receptors. J Appl Physiol (1985). 2001;91(4):1860-7.

41. Heldring N, Pike A, Andersson S, Matthews J, Cheng G, Hartman J, et al. Estrogen receptors: how do they signal and what are their targets. Physiol Rev. 2007;87(3):905-31.

42. Kim JK, Hann HJ, Kim MJ, Kim JS. The expression of estrogen receptors in the tenosynovium of postmenopausal women with idiopathic carpal tunnel syndrome. J Orthop Res. 2010;28(11):1469-74.

43. Rao BR, Wiest WG, Allen WM. Progesterone "receptor" in rabbit uterus. I. Characterization and estradiol-17beta augmentation. Endocrinology. 1973;92(4):1229-40.

44. Blows FM, Driver KE, Schmidt MK, Broeks A, van Leeuwen FE, Wesseling J, et al. Subtyping of breast cancer by immunohistochemistry to investigate a relationship between subtype and short and long term survival: a collaborative analysis of data for 10,159 cases from 12 studies. PLoS Med. 2010;7(5):e1000279.

45. Purdie CA, Quinlan P, Jordan LB, Ashfield A, Ogston S, Dewar JA, et al. Progesterone receptor expression is an independent prognostic variable in early breast cancer: a population-based study. Br J Cancer. 2014;110(3):565-72

46. Carroll JS, Hickey TE, Tarulli GA, Williams M, Tilley WD. Deciphering the divergent roles of progestogens in breast cancer. Nat Rev Cancer. 2017;17(1):54-64

47. Siersbæk R, Kumar S, Carroll JS. Signaling pathways and steroid receptors modulating estrogen receptor a function in breast cancer. Genes Dev. 2018;32(17-18):1141-54.

48. Hsieh JL, Jou IM, Wu CL, Wu PT, Shiau AL, Chong HE, et al. Estrogen and mechanical loading-related regulation of estrogen receptor- $\beta$ and apoptosis in tendinopathy. PLoS One. 2018;13(10):e0204603.
49. Motta GR, Amaral MV Rezende E, Pitta R, Vieira TC, Duarte ME et al. Evidence of genetic variations associated with rotator cuff disease. $J$ Shoulder Elb Surg. 2014;23(2):227-35

50. Teerlink CC, Cannon-Albright LA, Tashjian RZ. Significant association of full-thickness rotator cuff tears and estrogen-related receptor- $\beta$ (ESRRB). J Shoulder Elb Surg. 2015;24(2):e31-5.

51. Bonato LL, Quinelato V, Pinheiro AR, Amaral MV, de Souza FN, Lobo JC, et al. ESRRB polymorphisms are associated with comorbidity of temporomandibular disorders and rotator cuff disease. Int J Oral Maxillofac Surg. 2016:45(3):323-31.

52. Tashjian RZ, Granger EK, Zhang Y, Teerlink CC, Cannon-Albright LA. Identification of a genetic variant associated with rotator cuff repair healing. J Shoulder Elb Surg. 2016;25(6):865-72.

53. Brandi ML, Crescioli C, Tanini A, Frediani U, Agnusdei D, Gennari C. Bone endothelial cells as estrogen targets. Calcif Tissue Int. 1993;53(5):312-7.

54. Cullinan-Bove K, Koos RD. Vascular endothelial growth factor/vascular permeability factor expression in the rat uterus: rapid stimulation by estrogen correlates with estrogen-induced increases in uterine capillary permeability and growth. Endocrinology. 1993;133(2):829-37.

55. Lieberman EH, Gerhard MD, Uehata A, Walsh BW, Selwyn AP, Ganz P, et al. Estrogen improves endothelium-dependent, flow-mediated vasodilation in postmenopausal women. Ann Intern Med. 1994;121(12):936-41.

56. Mendelsohn ME, Karas RH. Estrogen and the blood vessel wall. Curr Opin Cardiol. 1994;9(5):619-26.

57. Ao A, Wang H, Kamarajugadda S, Lu J. Involvement of estrogen-related receptors in transcriptional response to hypoxia and growth of solid tumors. Proc Natl Acad Sci U S A. 2008;105(22):7821-6.

58. Papp B, Plath K. Pluripotency re-centered around Esrrb. EMBO J. 2012:31(22):4255-7.

59. Cipollaro L, Sahemey R, Oliva F, Maffulli N. Immunohistochemical features of rotator cuff tendinopathy. Br Med Bull. 2019;130(1):105-23.

60. Franceschi F, Longo UG, Ruzzini L, Rizzello G, Maffulli N, Denaro V. The Roman Bridge: a "double pulley - suture bridges" technique for rotator cuff repair. BMC Musculoskelet Disord. 2007;8:123.

61. Franceschi F, Longo UG, Ruzzini L, Rizzello G, Denaro V. Arthroscopic management of calcific tendinitis of the subscapularis tendon. Knee Surg Sports Traumatol Arthrosc. 2007;15(12):1482-5.

62. Uhthoff HK, Sarkar K, Maynard JA. Calcifying tendinitis: a new concept of its pathogenesis. Clin Orthop Relat Res. 1976;118:164-8.

63. Petersen W, Stein V, Bobka T. Structure of the human tibialis anterior tendon. J Anat. 2000;197(Pt 4):617-25

\section{Publisher's Note}

Springer Nature remains neutral with regard to jurisdictional claims in published maps and institutional affiliations.
Ready to submit your research? Choose BMC and benefit from:

- fast, convenient online submission

- thorough peer review by experienced researchers in your field

- rapid publication on acceptance

- support for research data, including large and complex data types

- gold Open Access which fosters wider collaboration and increased citations

- maximum visibility for your research: over $100 \mathrm{M}$ website views per year

At $\mathrm{BMC}$, research is always in progress.

Learn more biomedcentral.com/submissions 